It requires no argument to show that, if appellants' property was so situated that it could not be utilized without injury to others, its use would not be permitted at all; and if the value of appellants' property was dependent upon other property which they did not own and could not acquire, then, as shown by the appellants themselves, the property had no value, and, of course, was not damaged. We think the instruction was proper in this case. ${ }^{\mathrm{x}}$

The analogy of these cases to the central theme of this note is the similarity between the position of the tenants whose rights would be affected if building, health, and sanitation violations would continue in the future and the third parties whose rights were given implicit protection in the cases in this category. For a purchaser would pay the value attributable to illegal use only on the premise that such illegal use could continue unabated. Certainly, a tenant has the same right to have the condition of the premises which he occupies bear a reasonable relation to the rent he pays as the unknown third parties in the Ladd case had not to have rocks thrown on them.

If an effective slum clearance and redevelopment program is to be carried on, one of the outstanding problems to be met is the high cost of land acquisition. A significant factor tending to maintain such costs is the disregard for building, health, and sanitation laws; the combination of over-crowding and low maintenance costs increases profits whose capitalized value gives to the property a value far above what such value would be were there effective law enforcement. The significance of this factor is indicated by the action of the English and New York legislatures in prohibiting compensation in condemnation proceedings for value attributable to illegal use. There is sufficient common law authority to justify courts in arriving at the same result without specific statutory help.

\title{
LANDLORD AND TENANT AFTER OPA
}

Federal control of the landlord-tenant relationship under the Emergency Price Control Act of $I 942^{x}$ is at best a stop-gap. Its purpose is to supplement state statutes and common-law rules clearly inadequate for dealing with a housing shortage greatly aggravated by mobilization for war. ${ }^{2}$ In view of the rapid termination of other emergency measures and the continuing attack on OPA, it is timely and important to anticipate what effect the end of rent and eviction controls will have on the landlord-tenant relationship. Inevitably, the nature of that relationship is itself somewhat obscure, for the more common types of

sx Portland \& Seattle Ry. Co. v. Ladd, 47 Wash. 88, 95, 9x Pac. 573, 576 (xgo7).

× 56 Stat. 25 (I942), as amended 57 Stat. 566 (I943), 58 Stat. 633 (I944), 59 Stat. 306 (x945), 50 U.S.C.A. $\$ 902$ (b) (r944).

${ }^{2}$ See Borders, Emergency Rent Control, 9 Law \& Contemp. Prob. I07 (1942) for a discussion of the relocation of population, the motivations therefor, and the effect of such relocation in creating inflationary rent increases of considerable magnitude. 
tenancy which have arisen under OPA are different from those prevalent before I942.

The purpose of this discussion is to examine how the problems arising from these tenancies will be worked out after the termination of federal control, and to test the adequacy of existing state law not only to meet the emergency of a continuing housing shortage ${ }^{3}$ but to satisfy the longer-range public concern for an equitable landlord-tenant relation. The approach to these important policy questions will thus be through an analysis of the different types of tenancy which are common today: I) tenancies existing under a termination-clause lease; 2) tenancies which were originally created by lease but which will be holdovers upon the termination of federal controls; and 3) tenancies in which no lease was ever executed by the parties. Throughout the discussion primary attention will be given to Illinois law.

Termination-clause lease. Almost all leases now in effect contain clauses providing for termination upon the expiration or repeal of rent control. ${ }^{4}$ The OPA has recognized the validity of this termination clause since it does not obligate the tenant for more than the present maximum rent but merely provides an opportunity for the negotiation of new terms upon the cancellation of the existing lease. 5 Where, however, the tenant has been asked to sign a renewal lease containing a termination clause, he need not sign and can remain in possession provided the expiring lease did not contain such a clause, ${ }^{6}$ since the federal rent regulations require that a tenant sign a renewal lease only "on the same terms and conditions as the previous lease." 7 Nevertheless, many tenants, uninformed as to their rights or anxious to maintain or secure the goodwill of their landlords, have entered into these termination-clause leases. Consequently, upon the expiration of federal rent control, the landlord can invoke this clause by giving the requisite notice, usually thirty or sixty days, and can demand a substantial increase in rent as a condition for creating a new tenancy. If the tenant refuses to comply, the landlord has recourse to the local eviction remedies. There is little doubt that the Illinois courts will recognize these clauses.

Holdover tenancy. A more ambiguous situation will arise where the lease has expired during the period of rent control and has not been renewed, either because the tenant refused to sign in view of a variance in the terms and conditions

3 The scope of this note has been restricted to residential rental units since they are the nation's most immediate concern.

4 The inclusion of such a clause is recommended by the Chicago Real Estate Board. See Chicago Real Estate Board Form ro-M.

5 Rent Regulations for Housing with Official Interpretations, Interpretation 4 -XI, $\S 4$ (July, 1945).

${ }^{6}$ Ibid.

7 Tbid., $\S 6(\mathrm{a})(\mathrm{I})$; 222 East Chestnut Street Corp. v. Murphy, 325 Ill. App. 392, 60 N.E. 2d $45^{\circ}$ (I945). 
of the new lease or because no new lease was proffered. It would seem that if the landlord failed to give the proper statutory notice of termination or change in the term of the tenancy prior to the expiration of federal rent control, a holdover tenancy would be created merely by the tenant's remaining in possession. ${ }^{8}$ The Illinois courts have consistently held that where a tenant for a year or other definite term holds over after his lease has expired, remaining in possession and paying his rent ${ }^{9}$ without any specific agreement as to the term, he shall be considered a tenant from year to year, and the covenants in the prior lease shall be binding upon both parties. ${ }^{\text {Io }}$

In New York after World War I, however, the Court of Appeals held that a tenant holding over under the local emergency rent laws did not become a tenant from year to year because the elements of offer and acceptance, express or implied, were absent. Ix The court proceeded on the theory that a tenant holding over subject to the conditions of the original lease might be treated as a tenant from year to year only on the basis of an option, implied in law, tendered by the tenant to the landlord which the latter is at liberty to accept or reject. Since the emergency rent laws suspend possessory remedies under the lease against the will of the landlord, the tenant remains in possession, not by any agreement, express or implied, but by compulsion of law. In this circumstance the landlord is tendered no option, and consequently the conventional relation of landlord and tenant cannot be inferred. The tenant has only his statutory rights as the measure of his term and liability.

This New York view fails to recognize that the landlord's situation under moratorium legislation is far from hopeless, since he can always give the proper statutory notice to create a lesser periodic tenancy, thereby permitting prompt termination of the relationship once controls are lifted.

If the Illinois precedents are followed, a holdover tenant will be protected from eviction or a rent-boost after the removal of controls until the end of the holdover term - a year at most-at which time the landlord can terminate the tenancy. ${ }^{\mathrm{x}}$ If, however, the landlord gives proper statutory notice to the tenant

8 The federal rent control regulations do not nullify the local laws but merely place certain local remedies in abeyance for the duration of such controls unless resort to these remedies is authorized by the Administrator. Consequently, although the landlord cannot evict the tenant, it would seem that he can, by providing proper statutory notice, create a tenancy for a lesser term.

9 Eppstein v. Kuhn, 225 Ill. I15, 80 N.E. 80 (rgo7). The acceptance of a month's rent by the landlord was considered the essential element evidencing a tenancy from year to year after the expiration of the original term.

${ }^{10}$ Bell v. Groom, 224 Ill. App. 58 (I922); Tivnen v. Gebhart, 268 Ill. App. 259 (I932); Cottrell v. Gerson, 296 Ill. App. 4 r2, I6 N.E. 2d 529 (1938). But cf. Conn. Gen. Stat. (I930) \$ 502I: "No holding over by any lessee, after the expiration of the term of his lease, shall be evidence of any agreement for a further lease ...."; Coleman v. Brigham, Ir5 Conn. 286, I6x Atl. 236 (1932).

"Stern v. Equitable Trust Co., 238 N.Y. 267 , 144 N.E. 578 (I924):

31 II. Rev. Stat. (I945) c. 80, § 5 requires sixty days' notice in writing to terminate tenancies from year to year. 
while federal controls are still in effect, the relationship presumably would be that of a tenancy without a lease, the landlord being free to demand an increased rental or to evict almost immediately after the termination of controls.

Tenancy reithout a lease. Where the tenant assumed possession of the premises without a lease, the nature of the rent paid or reserved determines the character of the periodic tenancy, unless a different intention is expressed. If the rent is paid on a monthly basis, as it usually is, the tenancy is deemed to be from month to month. ${ }^{13}$ Where the rent is paid on a weekly basis, a periodic tenancy from week to week results:

Under this type of tenancy the obligations of the landlord are minimal, the general doctrine being that in the absence of a lease, agreement, express warranties, fraud, or misrepresentation, the tenant takes the property as he finds it. There are no implied covenants or warranties that the premises shall be tenantable, fit, or suitable for habitation. ${ }^{14}$ Nor is there any implied covenant that the premises, habitable at the time of demise, will continue to be habitable during the term. ${ }^{.5}$ Thus should the heating or plumbing system fail, courts holding this view would place no burden upon the landlord to repair it. ${ }^{16}$ Of course, the tenant can terminate the tenancy on short notice should the failure to repair result in intolerable living conditions, but this is not a real alternative during a housing shortage. The tenant, however, is subject to an implied obligation to do no substantial injury to the premises through negligence or willful misconduct. ${ }^{17}$

The only covenant implied for the benefit of the periodic tenant is the covenant of quiet and peaceable possession and enjoyment. Its effect is to require the landlord to protect the tenant from any interference with the use and enjoyment of the premises for the duration of the tenancy by any paramount title claimant, by anyone in privity with the landlord, or by the landlord himself. ${ }^{8}$

${ }_{3}$ Donohue v. Chicago Bank Note Co., 37 Ill. App. $55^{2}$ (I89I); Sebastian v. Hill, 5 I Ill. App. 272 (1893).

${ }_{4}$ The doctrine of caveat emptor is invoked. Rubens v. Hill, II5 Ill. App. 565 (1904); Martin v. Surman, II6 Ill. App. 282 (1904); Cromwell v. Allen, 15I Ill. App. 404 (I909); Russell v. Clark, I73 Ill. App. 46I (I9I2). But cf. the English cases, Smith v. Marrable, II M. \& W. 5 (r843) and Collins v. Hopkins [1923] 2 K.B. 6r 7, where a warranty of fitness for habitation was implied in law. In the United States this English doctrine has been rejected with but one exception, Ingalls v. Hobbs, 156 Mass, 348, 3 I N.E. 286 (I892).

is Moore v: Weber, 7r Pa. 429 (I872); York v. Steward, 2r Mont. 515, 55 Pac. 29 (I898).

${ }^{16}$ Breazeale v. Chicago Title \& Trust Co., 293 Ill. App. 269, I2 N.E. 2d 217 (I938); Farmer v. Alton Building \& Loan Ass'n, 294 Ill. App. 206, 13 N.E. 2d 652 (1938); Hollywood Bldg. Corp. v. Greenview Amusement Co., 315 Ill. App. 658, 43 N.E. 2d 566 (1942). Cf. New York where the Tenement House Law (McKinney, I9I8) c. 6r, $\$$ Io2 has imposed a duty to repair upon the owner which is independent of contract. The duty to repair is one imposed by law with liability in tort where the duty is ignored. Altz v. Leiberson, 233 N.Y. I6, 134 N.E. 703 (I922).

${ }^{17}$ Keogh v. Peck, 3 I6 Ill. 3I8, I47 N.E. 266 (I925); United States v. Bostwick, 94 U.S. 53 (1876).

${ }^{18}$ Wade v. Halligan, I6 Ill. 507 (I855); Gozzolo v. Chambers, 73 Ill. 75 (I874); Berrington v. Casey, 78 Ill. 317 (1875); Muller v. Bernstein, 198 Ill. App. IO4 (1916). 
However, if the interference is by a stranger to the title or a trespasser, the implied covenant is not broken and the landlord is not liable. ${ }^{19}$

It is obvious that the tenant without a lease is at a serious disadvantage. The landlord has no obligation to provide habitable premises, maintain the premises in repair, decorate, or renew the term. And with the expiration of federal rent control the landlord can terminate such tenancies almost immediately, simply by giving the requisite notice-thirty days' notice for all monthly tenancies and a reasonable notice for weekly tenancies. ${ }^{20}$ The implied covenant of quiet possession affords little or no protection since the duration of the tenancy is so limited.

Thus the tenancies which have become prevalent under federal rent control will, in the majority of cases, be subject to termination within a relatively short period after the expiration of such control. ${ }^{2 x}$ The tenant may be required to pay exorbitant rentals as a condition of continued possession, and even though willing to pay he can nevertheless be evicted if the landlord so desires. Some idea as to what may happen can be gained by recalling a few of the incidents accompanying the temporary abandonment of federal controls in July, r946. Although landlords were advised by real estate associations not to act hastily, lest Congressional action be precipitated, "mailbags bulged with thousands of eviction notices." ${ }^{22}$ Existing state law was hopelessly inadequate. The Chief Justice of the Chicago Municipal Court announced the abolition of the Renter's Court and the distribution of its eviction cases to the sixteen trial courts in an effort to eliminate the confusion pending legislative relief. ${ }^{23}$ It is reasonable to assume that if controls are permanently removed in the near future the least serious consequence will be a complete breakdown in the judicial machinery. ${ }^{24}$

\section{II}

The crisis which will be precipitated by the removal of federal controls, with its obvious repercussions on our entire social structure, affords an excellent op-

19 Gozzolo v. Chambers, 73 Ill. 75 (1874); Field v. Herrick, I4 Ill. App. I8I (I884).

${ }^{30}$ See Dunne v. Trustees of Schools, 39 Ill. 578 (1864), where the court held that all tenancies of less than one year and greater than one month, including a tenancy from month to month, required thirty days' notice, but that it would be absurd to require such notice to terminate tenancies of less than one month.

${ }^{21}$ H. J. Res. 37I, 79th Cong. 2d Sess. (Pub. L. 548, July 25, 1946) extended federal rent controls to June 30,1947 .

${ }^{22}$ Chicago Sun, p. I, col. I (July 4, I946), p. I, col. 3, (July 21, 1946).

${ }_{23}$ Chicago Sun, p. 3, col. I (July 23, I946).

${ }^{24} \mathrm{It}$ would seem, however, that the federal courts might enjoin any attempts to enforce a lease clause permitting the landlord to increase the rental upon the expiration of federal rent controls without providing the tenant an opportunity to terminate the lease. The OPA has ruled such a clause invalid, since it could be used as a means of obtaining after rent control rent which was in fact consideration for the use and occupancy of the premises during rent control. Rent Regulations, op. cit. supra note 5 at $\S 3$. 
portunity to examine the landlord-tenant relationship in the light of its historical development in order to determine its adequacy for the problems which lie ahead. And, if a chaotic situation attendant upon the expiration of federal rent control is to be avoided, such a critical examination must be made now while there is yet time to provide remedies.

Historical Development. Originally the subject matter of a lease was land. The creating instrument, therefore, was understandably regarded as a conveyance, and the common-law covenants surrounding such a conveyance were not concerned with the condition of any dwelling house incidentally located upon the land. As the primary object of the tenancy changed, it became necessary to include many contractual obligations in the same instrument which evidenced the conveyance; thus the lease became a combination contract and conveyance. ${ }^{25}$ The modern residential lease is no longer an interest in land; the primary concern is the occupancy of living quarters, not the cultivation of land, and hence the urban landlord-tenant relationship is more of a bailment than a conveyance.

The majority of jurisdictions, looking to the origin of the lease, regard the covenants generally found in leases as independent of one another, since the granting of the leasehold estate is held to constitute the consideration for all covenants made by the tenant. ${ }^{26}$ Thus a breach by the landlord of a covenant to repair does not, under this approach, excuse the tenant from his obligation to pay rent. The minority view, which treats the lease as a bilateral contract, excuses the tenant from performance if there has been a fundamental breach by the landlord.27 This latter position would certainly seem to be the more realistic, $^{28}$ since the modern lease, characterized by numerous covenants reflecting the strength of organized landlord groups as well as the change in function of the instrument, bears little resemblance to the common-law conveyance.

The conveyance concept is particularly anomalous in its application to a non-lease tenancy. In this situation, as has been seen, the courts tend to ignore the real nature of the residential tenancy and apply to it common-law covenants developed at a time when tenancies were interests in land.

${ }^{25}$ Berman v. Holdsworth, 274 Mass. 260, r74 N.E. 478 (193I); x Tiffany, Real Property $\S 87$ (1939); 3 Williston, Contracts $\$ 890$ (1936).

${ }^{26}$ Palmer v. Meriden Brittania Co., I88 Ill. 508, 59 N.E. 247 (I90r), aff'g 88 Ill. App. 485 (1899); I Tiffany, Real Property $\$ 87$ (1939).

27 In University Club of Chicago v. Deakin, 265 Ill. 257, 106 N.E. 79० (Igr4), a landlord covenanted in the lease not to rent to any other person engaged in selling jewelry. The defendant lessee quit the premises and refused to pay the rent upon a breach of this covenant. The court held that the plaintiff's breach excused the tenant from further performance. Although this decision does provide relief for the tenant on a contractual basis, the Illinois courts have not extended this approach to residential leases generally. See also Berman v. Shelby, 93 Ark. 472, I25 S.W. I 24 (Igro); Ashmore v. Hays, r 59 Ark. 234, 252 S.W. I ( (1923); Higgins v. Whiting, 102 N.J.L. 279, I31 Atl. 879 (1926).

${ }^{28}$ The civil law regards a lease as a bilateral agreement. Viterbo v. Friedlander, I20 U.S. 707 (1887). 
Standard-Form Leases. An examination of the covenants surrounding the typical modern tenancy is necessary to an understanding of the relationship. The great majority of lease tenancies are created by standard-form leases promulgated by landlord organizations or based on provisions similar to those found in such leases. ${ }^{29}$

The widespread acceptance of standard leases by tenants indicates a marked inequality in the bargaining power of the parties. This inequality has resulted in the dictation of terms by the landlord and their acceptance, of necessity, by the tenant. The combination of landlords into large and influential groups has encouraged the standardization of these terms.

The first fairly widespread use of the standard-form leases occurred around r895. Since then they have been adopted by practically all landlords, whether members of any landlord organization or not. The provisions embodied in these standard-form leases have expanded rapidly and now constitute a comprehensive scheme of landlord immunity, together with an extensive enumeration of the tenant's duties. Prior to the last decade, a tenant who was fully aware of the significance of the provisions could demand that they be stricken from the lease and more favorable provisions substituted, since there was then a greater equality of bargaining power. There has always been, of course, a large class of uninformed tenants who were unaware of the significance of many of the provisions and who executed without question the standard-form leases presented to them. The housing shortage has forced even the informed tenant to accept these leases in order to obtain accommodations.

Courts in many instances have recognized this inequality of bargaining power and have attempted to protect the tenant by applying to the lease two related rules of construction: $r$ ) an instrument will be construed most strongly against the party who drafted it; ${ }^{30}$ 2) where a covenant is doubtful in its language and susceptible of two interpretations, the construction most favorable to the tenant will prevail. ${ }^{x x}$ Generally the tenant gains nothing from this judicial solicitude, since the landlord organizations merely have their corps of attorneys draft an additional stipulation for the standard-form lease resolving all doubtful situations in their favor.

The need for a uniform lease equalizing the rights of landlords and tenants becomes painfully obvious when certain of the standard provisions, currently in use, are scrutinized. One standard provision expressly authorizes the landlord to terminate the lease by reason of the tenant's breach of a covenant or his sub-

\footnotetext{
29 Holdover tenancies are also subject to these provisions since the terms of the original lease remain effective.

${ }^{30}$ Phoenix Ins. Co. v. Slaughter, I2 Wall (U.S.) 404 (1870); Continental Oil Co. v. Fisher Oil Co., 55 F. $2 d I_{4}$ (C.C.A. Ioth, I932).

${ }^{31}$ Goldberg v. Pearl, 306 Ill. 436, I38 N.E. I4I (x923); The Cheat Mountain Club v. West Virginia Pulp \& Paper Co., 205 Fed. 195 (D.C. W.Va., I913); Pierce v. New York Dock Co., 265 Fed. 148 (C.C.A. 2 d, 1920).
} 
sequent insolvency. Thus the landlord is given a possessory as well as a contractual remedy. ${ }^{32}$ It would seem that the landlord should be restricted to his contractual remedy in the absence of an adjudication by a court or responsible administrative body as to whether the tenant has committed an actual breach and, if so, whether such breach was justifiable. Otherwise, this provision may result in an unwarranted eviction by the landlord.

If a lease permits the landlord to terminate because of a breach, the tenant should at least be entitled to notice and an opportunity to cure the default and avoid forfeiture, ${ }^{33}$ especially since certain breaches may be inadvertent. ${ }^{34}$ It would also seem apparent that not all of the tenant's covenants are of equal importance. Certainly a covenant to use the laundry facilities at specified times only is less significant than the covenant to pay rent.

Provisions waiving all the tenant's rights to "demand for rent, notice to quit, demand for possession and any and all notices and demands which may or shall be required by any statute of this State relating to forcible entry and detainer, or to landlord and tenant, or any other statute or law," ${ }_{35}$ constitute an outright perversion of the legislative intent and violate accepted notions of due process but are nonetheless countenanced by the courts. ${ }^{36}$ The power of attorney provision, authorizing a confession of judgment and waiver of process and trial by jury, has been drastically abrogated by statute in some states ${ }^{37}$ as violative of public policy and as depriving citizens of the protection of the courts. ${ }^{8}$ The Illinois courts, however, have permitted such warrants of attorney

${ }^{32}$ In re Wil-low Cafeterias, 95 F. 2d 306 (C.C.A. 2d, 1938); Meighan v. Finn, I46 F. 2d 594 (C.C.A. 2d, I944).

${ }_{33}$ Note the Illinois position in Clark v. Stevens, 22I Ill. App. 233 (I92I), which supports a waiver by the tenant of notice from the landlord that the lease has terminated by virtue of a breach by the tenant of the covenant to pay rent. See also Chicago Real Estate Board Form No. xo-C, par. $x_{4}$.

${ }^{34}$ For example, where the tenant's insolvency or receivership proceedings are involuntary.

35 Chicago Real Estate Board Form ro-M, par. 15.

${ }^{36}$ Espen v. Hinchcliffe, I3I Ill. 468, ${ }_{33}$ N.E. 592 (I89o); Belinski v. Brand, 76 Ill. App. 404 (1898); Cote v. Landow, 240 Ill. App. 292 (x926). See also Chicago Real Estate Board Form 10-C, par. 15. But cf. 222 East Chestnut Street Corp. v. Murphy, 325 Ill. App. 392, 60 N.E. $2 d 450$ (1945), where the court held a provision waiving notice to quit and demand for possession repugnant to the federal rent regulations.

37 "(I) Any power of attorney to confess judgment or to suffer judgment to pass by default or otherwise .... given before an action is instituted, is void. (2) No person shall appear for a defendant under any such power in any court in this state." Ky. Rev. Stat. Ann. (Baldwin, r943) § 372.I40. Note also Mass. Ann. Laws (I944) c. 23I, § I3a; and Miss. Code Ann. (1942) $\S$ I545.

${ }^{38}$ In Irose v. Balla, I8I Ind. 49I, I04 N.E. 85 I (I9I4), the Indiana Supreme Court declared that in the absence of proof of an nllinois statute authorizing the execution of a note containing a power to confess judgment, it was presumed that such power to confess judgment would be invalid as obviously contrary to public policy. Apparently, this was not as obvious to the Illinois legislature as the Indiana court thought. 
authorizing confession of judgment for any amount due, ${ }^{39}$ and standard-form leases reflect these decisions. $4^{\circ}$

The exculpatory covenant, whereby the landlord expressly limits his tort liability for damages arising from any act or neglect by himself or his agent, ${ }^{4} \mathrm{is}$ particularly repugnant to notions of fair play. That any individual should be able to avoid tort liability by contracting away his own negligence seems clearly opposed to public policy since such provisions induce a want of care and increase the probability of negligent conduct.

The courts have indicated, usually by way of dictum, that such clauses will be given a narrow construction against the landlord; ${ }^{42}$ this has apparently meant that the landlord could be insulated from liability for nonfeasance only. The New York Court of Appeals, however, in Kirschenbaum v. General Outdoor Advertising $C_{0.43}$ gave such an exculpatory clause a literal construction and granted to a landlord immunity from liability for misfeasance, 44 thereby extending the right to anticipatory release of liability to landlords when it has been denied to employers, ${ }^{45}$ common carriers, ${ }^{46}$ and warehousemen ${ }^{47}$ in view of their superior bargaining power..$^{8}$ The New York decision was based in great measure upon a premise which cannot now be accepted-that the landlord and tenant stand upon equal terms, neither being under any compulsion to enter into an agreement..$^{49}$ In 1937 , the New York legislature, ${ }^{50}$ recognizing the un-

${ }^{39}$ Fortune v. Bartolomei, 164 IIl. 51, 45 N.E. 274 (1896); Stead v. Craine, 256 Ill. App. 445 (1930).

10 The designation by attorneys for landlords of their firm or of other attorneys within their firm as counsel for the tenant in confessing judgment reflects the disrepute in which such clauses are held, and seemingly violates the bar associations' Canons of Ethics.

4 Chicago Real Estate Board Form 10-M, par. 8.

${ }^{2}$ Worthington v. Parker, II Daly (N.Y.) 545 (1885); Randolph v. Feist, 52 N.Y. Supp. Iog (Sup. Ct., I898); Levin v. Habicht, 90 N.Y. Supp. 349 (Sup. Ct., I904). Contra: Cannon v. Bresch, 307 Pa. 31, I60 Atl. 595 (1932) (upholding a clause which exempted "from all liability for any and all damage caused by water." It was held that the word "all" includes everything and excludes nothing, and is obviously broad enough to include exemption from liability for affirmative negligence).

43258 N.Y. 489 , 180 N.E. 245 (x932).

14 Drescher Rothberg Co. v. Landeker, I40 N.Y. Supp. 1025 (Sup. Ct., I9r3); Kessler v. The Ansonia, 222 App. Div. 148, 225 N.Y. Supp. 589 (I922).

45 Roesner v. Hermann, 8 Fed. 782 (C.C. Ind., I88 1 ); Hinrod Coal Co. v. Clark, 197 Ill. 514, 64 N.E. 282 (1902); Johnson v. Fargo, 184 N.Y. 379, 77 N.E. 388 (1906).

${ }^{6}$ Adams Express Co. v. Croninger, 226 U.S. 49 I (I9I3); American Fruit Distributors v. Hines, 55 Col. App. 377, 203 Pac. 821 (1921).

${ }^{47}$ Morse v. Imperial Grain \& Warehouse Co., 40 Col. App. 574, I8x Pac. 815 (I9r9); Adler v. Bush Terminal Co., 29 I N.Y. Supp. 435 (Sup. Ct., 1936).

${ }_{4}^{8}$ See Significance of Comparative Bargaining Power in the Law of Exculpation, $37 \mathrm{Col}$. L. Rev. 248 (I937).

49 This result followed earlier decisions in other jurisdictions to the same effect. Clark v. Ames, 267 Mass. 44, 165 N.E. 696 (1929); Cannon v. Bresch, 307 Pa. 3r, I60 Atl. 595 (1932).

50 N.Y. Real Property Law (McKinney, I945) c. 49, § 234. "Every covenant, agreement or understanding in or in connection with or collateral to any lease of real property exempting the 
healthy effects of the Kirschenbaum case, declared negligence-exempting clauses in lease transactions void and unenforceable as against public policy. ${ }^{5 \mathrm{I}}$

Illinois would do well to adopt such an approach. Complete insulation from affirmative negligence can never be defended. The landlord is the only one upon whom can be placed the burden of maintaining those portions of the premises used in common by all tenants; further, he is in the best position to administer the risk incident to the operation of the premises. The only effective way in which that burden can be placed on the landlord is to hold him liable for all negligence, nonfeasance as well as misfeasance. A properly bargained rental would reflect the costs of necessary inspection, maintenance, and insurance.

Although generally the courts have held that the landlord has no duty to repair the premises in the absence of an express stipulation to repair, a Montana court in York v. Steward ${ }^{52}$ held that the flowing of water into tenanted apartments because of defective plumbing which the landlord refused to remedy constituted a breach of theimplied covenant of quiet enjoyment. ${ }^{33}$ Thus courts could afford tenants a measure of protection in the presentemergency by extending the implied covenant of quiet enjoyment to any number of similar hardship cases where the premises have become untenantable. Those courts which regard a lease as a bilateral agreement by which the landlord promises a continuing permission to occupy the premises might easily analogize this tenancy agreement to the ordinary contract of sale of goods. Such contracts of sale have been interpreted to include a warranty of fitness for use. These courts should have no diffculty in implying a similar warranty of fitness for use where there is a contract of "sale" of the use of a residential unit. The courts have repeatedly contended that they will declare implied covenants to exist when it is necessary to imply certain duties and obligations in order to effect the purpose of the parties to the agreement. 54 Can it be doubted that the tenant reasonably expected complete and undisturbed possession of habitable premises? Clearly it is necessary either to extend the scope of the implied covenant of quiet enjoyment or to introduce implied covenants of continued habitability in order to give effect to the concept of the tenancy originally had by the parties. Unfortunately, the broadening

lessor from liability for damages for injuries to person or property caused by or resulting from the negligence of the lessor, his agents, servants or employees in the operation or maintenance of the demised premises or the real property containing the demised premises shall be deemed to be void as against public policy and wholly unenforceable."

ss Bernard Katz, Inc. v. East Thirtieth Street Corp., I72 Misc. 873, İ N.Y.S. 2d 640, aff'd 259 App. Div. 707, x9 N.Y.S. 2d 445 (1939).

52 2I Mont. 515, 55 Pac. 29 (I898).

s3 See Boreel v. Lawton, go N.Y. 293 (1882) and Vann v. Rouse, 94 N.Y. 401 (1884) which indicate that the New York court may be persuaded to extend the implied covenant of quiet enjoyment to situations where there was no actual entry or physical disturbance by the landlord, but merely an omission by the landlord of properly maintaining and keeping the premises in repair.

54 Freeport Sulphur Co. v. American Sulphur R. Co., II7 Tex. 439, 6 S.W. 2 d 1039 (Ig28). 
of existing common-law concepts by judicial legislation is a slow and laborious process.

A modern lease, drafted by informed representatives of both tenant and landlord organizations, clearly recognizing the nature of the residential tenancy, would perhaps be the most desirable answer to the problems presented by the unilateral form lease now so widely used. Favorable results in this direction have been realized with farm tenancy and sharecropping arrangements. ${ }^{55}$ The lack of effective organization among urban tenants, however, makes it unlikely that similar results can be obtained with residential leases in the near future.

\section{III}

State legislative action is the only effective means of coping with the emergency which will arise upon the termination of federal rent controls. Such action is justified under the police power since a housing emergency is a serious threat to the health, morality, comfort, and peace of the people. Reasonable regulation cannot be successfully attacked on the grounds that it contravenes the guaranties of due process and equal protection, or that it impairs the obligations of contracts.

What type of regulation is most likely to secure just and equitable results is a debatable question. In general, four major types of rent control legislation have been employed in the past.

In the leading case in this field, Block v. Hirsh,,$^{56}$ the Supreme Court through Mr. Justice Holmes upheld the creation of a rent commission in the District of Columbia under the Ball Rent Law. ${ }^{57}$ This law created a commission of three - members empowered to determine, upon their own initiative or upon complaint, whether housing rents, charges, or services were fair and reasonable. The commission had the power to fix fair and reasonable rents, services, or charges after a finding of unfairness and unreasonableness. Furthermore, tenants were permitted to continue in possession so long as they paid rent and otherwise complied with the terms of the tenancy, and they could be evicted only in a few limited instances set forth in the statute. Mr. Justice Holmes acknowledged the finding by Congress of an emergency and concluded that the business of renting had become affected with a public interest, thus justifying regulation of rents under the police power.

The second major type of rent control is best exemplified by the New York Emergency Housing Laws of $1920 . .^{8}$ This made available to a tenant in an action for rent the defense that the rent charged was oppressive and unreasonable.

${ }_{55}$ See Better Farm Leases, Farmer's Bulletin No. x 69 , U.S. Dept. of Agriculture, and A Step Forward in Farm Leases, the Country Gentleman (October, 1945).

${ }^{66} 256$ U.S. I35 (I92I). Also note in this connection Marcus Brown Co. v. Feldman, 256 U.S. I70 (I92I).

${ }^{57} 4 \mathrm{I}$ Stat. 298 (1919), c. 80, tit. II (Act of Oct. 22, 1919).

${ }^{8}$ N.Y. Housing Laws (1920) c. 136 , as amended by c. 944 . 
As a further aid, the statute provided that where the increase in rent was in excess of 25 per cent in one year, the lease or agreement was presumptively unjust, unreasonable and oppressive. ${ }^{59}$ Massachusetts ${ }^{60}$ and New Jersey ${ }^{6 t}$ enacted similar statutes providing standards of reasonableness.

The third major method of rent control involved the creation of a "fair rent" court to administer a "fair rent" law. ${ }^{62}$ The interesting feature of this New South Wales technique was the comprehensiveness of the scheme for determining the fair rent. If the court was convinced that the situation did not justify a rent increase, the rent was pegged at the rate at which the dwelling was rented exactly one year prior to the operation of the act. The determination of a fair rent involved consideration of the following factors: $\mathrm{I}$ ) the unimproved value of the land; 2) the cost of erecting a similar dwelling at the time of the application; 3) the interest to be allowed the landlord on the capital value arrived at by totaling the first two factors; and 4) the amount of taxes, expenditures for repairs, maintenance and renewal, and insurance. ${ }^{63}$

And finally, rent regulation under the Emergency Price Control Act of $1942^{6{ }^{6}}$ has taken the form of pegging rents as of a given date and prohibiting rentals higher than those received for the accommodations in question on that date. Thus the rent on that date becomes the maximum lawful rent, although necessary individual adjustments may be made. As pointed out previously evictions are curtailed, but a procedure has been established for granting them in exceptional cases.

It should be noted that although some of the above methods were dictated by wartime exigencies, others were drafted when post-war economic conditions necessitated the continuance of rent control. ${ }^{65}$ Furthermore, there is ample precedent for post-war regulation, even in Illinois.

In $192 \mathrm{x}$ the Illinois legislature recognized the existence of a housing emergency by placing a six months' moratorium on evictions to be granted in the discretion of the court upon application by the tenant, ${ }^{66}$ by suspending the payment of double rent on holdover tenancies, and by increasing the requisite

${ }^{59}$ In Levy Leasing Co. v. Siegel, 258 U.S. 242 (rg22), the United States Supreme Court held that the standard of reasonableness was sufficiently definite to comply with the due process clauses of the Constitution.

${ }^{60}$ Mass. Gen. Laws (rg21) c. 578.

61 N.J. Rev. Stat. (I924) c. 69, § 2.

62 New South Wales Acts (I915) No. 66.

${ }^{63} \mathrm{An}$ interesting review of the experience of New South Wales will be found in an article by H. V. Evatt, A Fair Rent Experiment in New South Wales, 2 J. Comp. Leg. \& Int. I. 10 (Jan., I920).

${ }^{6} 4$ Note I supra.

65 In addition, note the English Rent Act, Io and II Geo. V, c. I7 (1920).

${ }^{66}$ Ill. L. I921, at 466 , Ill. Rev. Stat. (I921) c. 57, adding $\$$ I 7 a. Extended by Ill. I. I923, at 407 and III. L. 1925, at $4 \mathrm{II}$. 
notice to terminate all tenancies for any term less than one year. ${ }^{67}$ Subsequent renewals extended this legislation to July $I,{ }_{1927}$, at which time the housing emergency was apparently deemed at an end and the provisions were permitted to expire. Thus there seems to be very little doubt that the business of renting dwellings for hire is affected with a public interest and is subject to appropriate state regulation.

New York has taken the lead in the present crisis by enacting an Emergency Housing Rent Control Law ${ }^{68}$ which does not become operative until federal controls are removed. During the special session of the Illinois General Assembly in July, 1946, bills were submitted which would provide for a freezing of rents at a fixed percentage over existing federal maximum rents and for a general moratorium on evictions for a definite period. ${ }^{69}$ These proposals are inadequate because of their inherent inflexibility which would result in hardship to both parties. A fixed percentage rental increase will often be excessive or else wholly inadequate. It is well recognized that roo per cent occupancy and curtailed services have in many instances more than compensated for the effects of a general rise in the price level. Consequently in these situations an increase in rents would not be equitable. Likewise, an infexible moratorium on evictions will work a hardship in those instances where a landlord has a legitimate and justifiable claim which at least deserves a hearing.

A sounder, although more complex, solution would be the establishment of a state rental housing commission. This commission would be clothed with such general powers and duties as to enable it effectively to forestall profiteering, speculation, and other disruptive practices in areas of residential housing shortage. Such a commission would consider eviction petitions on their individual merits, and in determining the maximum rents for any area subject to control would be free to consider evidence and recommendations submitted by interested parties. This flexibility would allow the commission to weigh such factors as the increased cost of maintenance, the rise in the general price level, and other circumstances peculiar to the locality in question.

In addition, this commission would also undertake a long range program of planning for effective residential tenancy. The desirable balance of rights and duties between landlord and tenant would be ascertained and a procedure for the enforcement of mutual obligations established, thereby relieving the courts of that burden. These obligations would be based upon the carefully determined allocation of the costs of repair, maintenance, decoration, and assumption of risk with respect to injury on the premises, with a corresponding adjustment of the rental figure to provide for a fair return on investment. The commission

${ }^{67}$ Ill. L. Ig2r, at 504, Ill. Rev. Stat. (x92x) c. 8o, amending $\$ \$ 2$ and 6. Extended by Ill. L. I923, at 428 and III. L. I925, at 459 .

68 N.Y. Unconsolidated Laws (McKinney, I946) $\$ \$ 858 \mathrm{I}-8594$.

69 Chicago Sun, p. 1, col. 2 (July 23, I946). 
would incorporate these mutual obligations into a lease which would be substituted for the present standard-form lease.

The establishment of such a commission or the assumption of these functions by an existing agency ${ }^{70}$ would be a long overdue recognition of the significance of the modern residential tenancy. Modifications which must be made in the landlord-tenant relationship can then be made in an ordered manner, instead of haphazardly and interstitially in the ordinary course of the judicial process.

\section{CONGRESSIONAL CONTEMPT POWER IN INVESTIGATIONS INTO THE AREA OF CIVIL LIBERTIES}

Newspaper reports of the past year have served to keep the House Committee on Un-American Activities close to the public spotlight. ${ }^{x}$ The contempt proceedings against Corliss Lamont, ${ }^{2}$ the one-man inquisition of Professor Harlow Shapley by Congressman Rankin, ${ }^{3}$ and the threat by the same legislator to investigate "subversive" activities in the American universities" again underline the problem of balancing the legislative need for information against the right of the citizen to privacy.

Legislative investigations and investigating committees are an accepted American political institution. While few would question the authority to hold

$7^{\circ}$ For example, the duties of the Illinois State Housing Board established by the State Housing Act of I933, Ill. Rev. Stat. (I945) c. 32, $\$ 504$, might well be expanded.

* This group operated as a temporary committee during its early years. At the first meeting of each new Congress a resolution continuing the committee had to be debated and adopted. At times extensions were given for limited periods within a given Congress. See H. Res. 282, 75th Cong. 3 d Sess. (1938); H. Res. 26, 76th Cong. Ist. Sess. (1939); H. Res. 90, 77th Cong. rst Sess. (194I); H. Res. 420, 77th Cong. 2d Sess. (1942); H. Res. 65, 78th Cong. Ist Sess. (1943). The committee was made permanent in 1945 with a slight change in name. H. Res. 5, 79th Cong. Ist Sess. (I945). From this time on, continuation of the committee would be effected by the virtually automatic procedure of adopting the rules of the previous House. The recent Congressional Reorganization Act has not altered the status of the committee. S. 2x77, 79th Cong. 2d Sess. (Pub. L. No. 6or, Aug. 2, x946).

${ }^{2}$ N.Y. Times, p. 4, col. 5 (June 27 , I946). In pursuance of an investigation of alleged Communist propaganda, the House Committee on Un-American Activities ordered production of all records of the National Council of American-Soviet Friendship, Inc. This organization operated as a relief agency during the war. A subpoena duces tecum was served upon Corliss B. Lamont, president of the corporation, and upon his failure to obey, the committee requested and received a contempt citation against him. 92 Cong. Rec. 7720-29 (June 26, I946). An identical citation was issued against Richard Morford for the same reason. 92 Cong. Rec. Io7ro (July $3^{\mathrm{x}, \text { I946). }}$

${ }_{3}$ N.Y. Times, p. 16, col. 4 (Nov. I5, 1946); Chicago Sun, p. I, col. 6 (Nov. 15, I946).

4 N.Y. Times, p. Ir, col. I (Dec. 26, I946); Chicago Sun, p. 5, col. 2 (Dec. 26, 1946).

5 The first Congressional investigation occurred in I792. 3 Annals Cong. 493 (I792); 2 Hinds, Precedents $\&$ 1725-26 (rgo7). Since then, Congress has exercised inquisitional power in approximately 500 separate instances. One writer counted $33^{\circ}$ investigations in the first 69 